\section{The Dialectic of the Sign in Claudio Rodríguez's Alianza y Condena}

I

n Alianza y Condena (1965), Claudio Rodríguez's third collection of poems, the poetprotagonist faces a dilemma that is at once semiotic and ethical: how is it possible simultaneously to participate in the world through language and to maintain one's critical vision of reality? The surrender of the self that, in all of Rodriguez's poetry, is the basis of a more authentic engagement with reality would appear to be incompatible with the search for the truth behind deceptive appearances. Alianza resembles Don de la ebriedad, Rodriguez's first book, in its more explicit concern with the problems of poetic language. As in Don, the poet attempts to overcome the duplicity of the linguistic sign in order to integrate himself once more into the world. The most significant difference, however, is that in the later book the poet's consciousness of the arbitrariness of the sign is irrevocable. The more innocent vision of reality to which he attempts to return is ultimately paradoxical.

The task facing the poet-protagonist of Alianza y Condena, then, is to reconcile language with the world, but without sacrificing his critical vision of both language and reality. In his attempt to resolve this dilemma he explores the ambiguities inherent in the notion of the arbitrariness of the sign. Language, although it is essentially deceptive, can also reveal the truth: its capacity to deceive, in fact, is inseparable from its capacity to uncover deceit. The "truth" concealed or revealed in language, in turn, is itself a duplicitous sign. The stripping of illusions normally unmasks a negative, destructive reality, but this reality itself might also conceal another, more positive truth. These exceptions to a predominately negative view of language allow
Dentro de la alianza existe la condena, igual que dentro de la condena existe la alianza. Es un proceso (para decirlo con una palabra muy cursi) dialéctico.

- Claudio Rodríguez

the poet to go beyond his critical vision and develop a more complete vision of the sign. A series of dialectical transformations of language leads to the rediscovery of innocence. ${ }^{1}$ This innocence, however, reveals a consciousness of its own fictionality: the poet remains fully aware that language is arbitrary, that it can only coincide with the truth in rare, exceptional moments of vision.

Alianza y condena not only marks a culminating moment in Rodríguez's own development as a writer, but also exemplifies a broader tendency in Spanish poetry of the 1960s toward a rigorously self-conscious concern with the ethical dimension of poetic language. The search for an authentic language that stands at the center of Alianza is the common preoccupation of many Spanish poets of the following decade. For writers such as José Angel Valente, Angel González, and Jaime Gil de Biedma, the social fabric of postwar Spain is based on a lie; language, along with other social conventions, serves primarily to conceal the truth. A common motif in Spanish poetry of the period is the "empty sign." Words have been so debased by their use as official discourse and propaganda that they have lost their capacity to tell the truth.

The younger poets' critique of a decadent and deceptive language is a variation and reversal of what Gustav Siebenmann has identified as one the commonplaces of "social poetry": "la denuncia de la vacua palabra literaria" (409). Whereas the social poets denounce the empty language of uncommitted, "dehumanized" poetry, Rodríguez's contemporaries extend their criticism of false language to the rhetoric of social poetry itself. Rodriguez speaks of 
falsos y taciturnos,

cebados de consignas, si tan ricos

de propaganda, de canción tan pobres (134).

This passage draws a clear link between duplicity, ideological dogmatism, and poetic sterility. Although this critique applies equally well to the official language of the Franco regime, in this case it refers primarily to the misuse of language on the left. The poetics of social poetry emphasize the ideal of a simple, transparent language: in order to regain a more authentic speech the poet has only to renounce the literary artifice that separates poetry from the masses. Implicit in the critical vision of Rodríguez and his contemporaries, in contrast, is an awareness of the more essential difficulty of reconciling language with the truth, even for the poet committed to social justice.

For the critical poet, the language of everyday social life is a series of euphemisms that mask the true nature of things. At the simplest level, the poet's task is to substitute more accurate names for these deceptive labels: "Jamás casas: barracas, / jamás calles: trincheras, / jamás jornal: soldada" (163-64). This denunciation of false language exposes a society that is based on a lie. The juxtaposition of the vast Castilian landscape and the decadence and corruption of Spain in this poem, "Ciudad de meseta," is reminiscent of Machado's Campos de Castilla and other works of the "Generation of '98." (José Luis Cano, among others, has made note of this kinship.) The direct denunciation of social ills, however, is uncharacteristic of Rodriguez's poetry. In "Brujas a mediodía," the poem that stands at the head of Alianza y Condena, the poet submerges himself in a world of duplicitous signs with little possibility of distinguishing truth from falsehood:

No son cosas de viejas,

ni de agujas sin ojo o alfileres

sin cabeza. No salta,

como sal en la lumbre, este sencillo

sortilegio, este viejo

maleficio. Ni hisopo

para rociar ni vela

de cera virgen necesita (127).

These first lines, which dissociate the witches from their traditional trappings, indicate the metaphorical nature of the title. The witchcraft here is not the conventional nocturnal variety, but rather the seemingly more mundane mystery of everyday reality, which the poet must confront in his search for knowledge: the subtitle of the poem is "(Hacia el conocimiento.)"2

The following lines explain the central metaphor in terms of the deceitfulness of the sensorial world, subtly reintroducing the negative connotations of witchcraft that had earlier been dismissed:

\section{Cada}

forma de vida tiene

un punto de cocción, un meteoro

de burbujas. Allí, donde el sorteo

de los sentidos busca

propiedad, allí, donde

se cuaja el ser, en ese

vivo estambre, se aloja

la hechicería. No es sólo el cuerpo,

con su leyenda de torpeza, lo que

nos engaña: en la misma

constitución de la materia, en tanta

claridad que es estafa,

guiños, mejunjes, trémulo

carmin, nos trastornaban. Y huele

a toca negra y aceitosa, a pura

bruja este mediodia de setiembre;

y en los pliegues del aire;

en los altares del espacio, hay vicios

enterrados, lugares

donde se compra el corazón, siniestras

recetas para amores (127-28).

Michael Mudrovic claims to detect a "sarcastic irony" in this first section of "Brujas." The condemnation of the illusory nature of material reality, however, is explicit rather than ironical. The irony, if anything, is that the poet still finds some attraction in such a sinister world. In spite of the denunciation of false illusions, the enchantment of the witches represents the poet's only hope either of participating in the world or of reaching the truth.

The second section of the poem marks a subtle change of tone from the first. The poet still views reality suspiciously, but his language becomes increasingly ambivalent as he searches for meaning in the deceptive images of the material world. Using a technique similar to that of the first lines of the poem, he contrasts the traditional ingredients of a witch's stew ("La flor del monte, la manteca añeja, / el ombligo del niño") to the more profound enchantment of everyday life:

todo lo que es cosa de brujas, cosa natural, hoy no es nada

junto a este aquelarre de imágenes que, ahora, cuando los seres dejan poca sombra,

da un reflejo: la vida.

La vida no es un reflejo

pero, ¿cuál es su imagen? (128-29)

The game of mirrors in this passage seems 
designed to confuse the reader. Life appears as the reflection of an image; it is thus at two removes from a more essential reality, barely glimpsed, perhaps, in the small shadows of "los seres." The last two lines here reverse this perspective: "la vida" is no longer a representation, but reality itself. The problem becomes one of distinguishing its true image.

The following series of questions reveals an even more ambivalent attitude toward the nature of knowledge, culminating in the central dilemma of whether it is preferable to preserve a comforting façade or to confront the truth head-on:

Un cuerpo encima de otro

¿siente resurrección o muerte? ¿Cómo envenenar, lavar

este aire que no es nuestro pulmón?

¿Por qué quien ama nunca

busca verdad, sino que busca dicha?

¿Cómo sin la verdad

puede existir la dicha? He aqui todo (129).

These lines echo the paradox of "Pinar amanecido," the final poem in Conjuros, in which the speaker implores his alter-ego to continue to live a lie rather than to face the destructive truth: "Nunca digas la verdad" (122). The injunction "do not believe what I am saying," however, is by definition impossible to obey. To acknowledge the contradiction between truth and happiness is already to privilege the truth, for the dilemma only exists after the illusion has already been exposed.

The concluding lines of "Brujas a mediodía" make it clear that the poet cannot remain apart from the material world, even as he recognizes it as a web of illusions:

$$
\text { Y ahora }
$$

a mediodía,

si ellas nos besan desde tantas cosas,

¿dónde estará su noche,

dónde sus labios, dónde nuestra boca

para aceptar tanta mentira y tanto

amor? (130)

The poet distrusts reality, but his suspicions do not lead him to an attitude of detachment. In his effort to strip away illusions he must engage reality with all of its deceptiveness. It is no longer possible simply to deny the deceptive nature of reality, living an illusory existence. Nor can the poet remain detached from these illusions, in a timeless world created by language (as in the visionary poetics of Don de la ebriedad). The unanswerable rhetorical questions with which he ends this poem exemplify the poet's fundamentally am- bivalent attitude toward the deceptive signs of the world. ${ }^{3}$

In several poems in Alianza y Condena the poet sees the signifier as a mask for the signified. In "Cáscaras," for example, language contains its meaning even as it conceals it, just as an envelope contains a letter (136-38). This image of the sign is a frequent one in the hermeneutical tradition. Interpretation is the process of unmasking the literal meaning in order to arrive at the truth contained within the text, the content within the form. Rodriguez's use of these topoi, however, often subverts this tradition, for the "truth" to be found behind language is a purely negative one. The poet discovers behind the facade the tautological truth that this facade is deceptive: the arbitrariness of the sign allows him a vision of the arbitrariness of the sign.

The attempt to unmask language, then, does not necessarily imply that there is anything of value behind it: "muerde aunque nunca llegues," the poet commands, search for the truth even though there is no certainty that you will ever find it (138). Furthermore, the process of unmasking the sign is not as simple as it might appear. The distinction between signifier and signified, the husk and the kernel of meaning it contains, is not always so straightforward. "Gestos," the poem which immediately follows "Brujas a mediodía," emphasizes the ambiguity of the sign rather than its deceptiveness. It is not that the sign appears to say one thing on the surface while concealing its true meaning (a lack of correspondence between signifier and signified), but that its very surface is slippery and indeterminate.

"Gestos" represents one of Rodríguez's most explicitly semiotic poems: it is one of the two poems in Alianza that directly speaks of "significación."4 It also provides the clearest example of the interrelationship between his meditation on the sign and his social and ethical preoccupations. The poem begins with a veiled political reference. The Spanish people can find salvation through a more authentic relation to the sign:

Una mirada, un gesto, cambiarán nuestra raza. Cuando actúa mi mano, $\tan$ sin entendimiento y sin gobierno, pero con errabunda resonancia, y sondea, buscando calor y compañía en este espacio en donde tantas otras han vibrado ¿qué quiere decir? 
The tone becomes more doubtful after the first sentence. The groping movement of the speaker's hand searches at once for understanding and for social solidarity, for truth and for love. Read in isolation, this passage might not appear metapoetic. In the context of Rodriguez's theory of the poetic act as an epistemological exploration of reality, however, the poet's gestures become a metaphor for the process of creation. The poet begins writing without knowing what the final result will be, and allows language itself to suggest the direction in which he will proceed. "La poesía," Rodríguez has suggested, "es una aventura lingüística" (Infame turba 229). ${ }^{5}$

The poet's gesture is not only a search for meaning, but also a sign to be interpreted. The most fundamental characteristic of this sign is its arbitrary randomness:

Cuantos y cuántos gestos como un sueño mañanero pasaron. Como esa

casera mueca de las figurillas

de la baraja, aunque

dejando herida o beso, sólo azar entrañable.

The metaphor of the chance configuration of a deck of cards points to a potential risk in the poet's irrational, intuitive approach to the sign. His linguistic play, which aims both to reveal some truth and to bring him into contact with other human beings, might produce only haphazard and therefore meaningless permutations of language. Both its negative and its positive meanings ("herida o beso") are basically accidental and contingent.

The random character of the sign, then, produces an ethical ambiguity as well as a semiotic one:

Más luminoso aún que la palabra,

nuestro ademan, como ella

roído por el tiempo, viejo como la orilla

del río, ¿qué

significa?

¿Por que desplaza el mismo aire el gesto de la entrega o del robo

el que cierra una puerta o el que la abre,

el que da luz o apaga?

¿Por qué es el mismo el giro del brazo cuando siembra que cuando siega

el del amor que el del asesinato.

The gesture is more "luminous" than the word because it is a motivated sign, one that directly reveals its meaning. Such "body language," in contrast to duplicitous speech, does not even seem to call for interpretation: "actions speak louder than words." This transpar- ence is nevertheless illusory, for the meaning, indeed the very identity of the gestural sign, is duplicitous. Two diametrically opposed "speech-acts" - giving and robbing, opening and closing, etc. - share an identical signifier. The gesture is at the same time more motivated and more ambiguous than the word, more closely connected to its meaning and more indeterminate.

The paradoxical status of the gesture dramatizes the speaker's ambivalence toward all signs. The second verse-paragraph reprises the political theme with which the poem began:

Nosotros, $\tan$ gesteros pero tan poco alegres, raza que sólo supo

tejer banderas, raza de desfiles,

de fantasías y de dinastias,

hagamos otras señas.

No he de leer en cada palma, en cada

movimiento, como antes. No puedo ahora frenar

la rotación inmensa del abrazo

para medir su órbita

y recorrer su emocionada curva.

No, no son tiempos

de mirar con nostalgia

esa estela infinita del paso de los hombres (131-32).

The poet's call for "other signs" to replace the empty and duplicitous gestures of political propaganda, which the poet must view with suspicion, clearly establishes the connection between his social and his linguistic denunciation. A cultural stereotype (Spaniards speak with their hands) serves to reveal a deeper characteristic of the "race": a propensity to substitute illusion for reality. The contrast between an illusory glory in the past, a decadence in the present, and a hope for the future calls to mind once again Campos de Castilla. Like Machado, the speaker here rejects nostalgia. Instead, he looks forward to the creation of a new language, one that he will no longer be obliged to distrust:

Hay mucho que olvidar

$\mathrm{y}$ más aún que esperar. Tan silencioso

como el vuelo del búho, un gesto claro,

de sencillo bautizo,

dirá, en un aire nuevo,

mi nueva significación, su nuevo

uso. Yo sólo, si es posible,

pido, cuando me llegue la hora mala,

la hora de echar de menos tantos gestos queridos,

tener fuerza, encontrarlos

como quien halla un fósil

(acaso una quijada aún con el beso trémulo)

de una raza extinguida.

Several critics have emphasized Rodríguez's irrationalism, which is reminiscent of the Sur- 
realist movement. ${ }^{6}$ In this case, however, the poet evokes the owl, a traditional symbol of reason and wisdom. The analogy of baptism implies at once a ritual cleansing of guilt, a rebirth, and an inaugural act of naming. The new sign will be transparent: "claro" and "sencillo" rather than opaque and arbitrary.

"Gestos," in its movement from a skeptical vision of social language toward a renovation of the sign, is a microcosm of Alianza y Condena. Although the poem serves to illustrate the poet's consciousness of the arbitrariness of all human communication, it also reveals the link between this arbitrariness and the renewal of hope. Paradoxically, it is only through his recognition of the ambiguity of the sign that the poet is able to transcend his narrowly critical view of the world.

The vision of the sign in a poem such as "Brujas a mediodía" is doubly negative: language is essentially deceptive, and it conceals a destructive truth. The ambiguity of the sign in "Gestos" is much more radical. The movement of the arm is not so much deceptive as it is arbitrary: it is not a pleasant façade that conceals an unpleasant reality, as in "Nieve en la noche" (159-60), but rather a neutral signifier that can refer to either violence or love. As in the conclusion of "Gestos," this radical arbitrariness allows the poet to go beyond the purely critical vision. The poems in "Libro tercero" invert the critical vision of language with which the poet began. Just as a seemingly negative sign can conceal a negative truth, the reverse is also possible: this negative "truth" can be the deceptive sign for another, more positive reality.

Rodríguez is a resolutely anti-confessional writer. In a revealing note in his introduction to Desde mis poemas he stops himself from delving into details of his life: "Estoy fallando. No quiero hablar de mi biografía" (18). The poems of the third section of Alianza, however, are among his most intensely personal. As their titles reveal, several appear to refer to specific events: "Un suceso," "En invierno es mejor un cuento triste," "Hacia un recuerdo," "Un momento." The indefinite article"Un olor," "Una luz," "Un bien"_-indicates the particularity of these experiences. At the same time, the anecdote is rarely explicit: an unnamed act of betrayal, which produces guilt and remorse, underlies several poems. As in Conjuros, the poet-protagonist attempts to atone for this unspecified failing in his past.
As Mudrovic observes, many of the poems in this section are based on the same paradox: "from evil, good arises" (254). The poet attempts to find redeeming value in his negative experience: "Ya se sabe / que el escorpión, la sanguijuela, el piojo / curan a veces" (182). The critic does not, however, consider this paradox in terms of Rodríguez's preoccupation with the sign. In "Un bien," good is concealed behind a deceptive veil; the poem employs the image of clothing, a traditional metaphor for the signifier: "A veces, mal vestido un bien nos viene; / casi sin ropa, sin acento, como / de una raza bastarda" (184). The poet's task, then, is to recognize the good in its shabby dress, to interpret a seemingly insignificant or negative sign in more transcendent terms. ${ }^{7}$ (This deciphering of the sign is a symmetrical reversal of the critical vision, the attempt to unmask the wolf in sheep's clothing.) The metaphor of song relates the interpretive activity to poetry itself: “¿Estamos sordos / a su canción tan susurrada, pobre / de notas?"

"Como el son de las hojas del álamo," like other poems in the third book, is based on the paradox of the negative sign. In this case, however, it is not a simple matter of "un bien" "mal vestido": the poem actually demonstrates the process by which a negative sign is transformed into an ambiguous and therefore potentially positive one. Along with "Gestos" it is one of Rodríguez's most explicitly metalingual poems. The poem begins with the transformation of an emotion into a sound:

El dolor verdadero no hace ruido; deja un susurro como el de las hojas del älamo mecidas por el viento, un rumor entrañable, de tan honda vibración, tan sensible al menor roce, que puede hacerse soledad, discordia, injusticia o despecho (178).

After converting his "dolor" into an auditory sound, the poet proceeds to interpret this sign. Like the branches of a tree, the sound bifurcates, becoming a "susurro," a "rumor," and a "vibracion." This multiplication of the signifier also yields new signifieds: a rather abstract emotion, "dolor," which can denote either physical pain or mental suffering, takes on a series of more concrete meanings. This process continues in the following lines, but with a significant change:

Estoy oyendo

su murmurado son, que no alborota

sino que da armoma, $\tan$ buido

y sutil, $\tan$ timbrado de espaciosa 
serenidad, que casi es ya cordura dolorosa, pura resignación.

The sound begins to gain independence from the emotion that it originally represented. At the same time its meaning, the "dolor" of the first line, loses some of its negative connotations. Instead of "injusticia o despecho," the speaker experiences more ambivalent and even positive feelings: serenity, sanity, and resignation. The adjective "pura" is significant here, for the original emotion is undergoing a process of purification. It is being neutralized through its transformation into music, an automous system of signs.

The next lines refer to the source of the poet's sorrow, an unidentified act of betrayal in the past:

Traición que vino

de un ruin consejo de la seca boca

de la envidia. Es lo mismo. Estoy oyendo

lo que me obliga y enriquece, a costa

de heridas que aún supuran.

It is unclear whether the speaker was the perpetrator or the victim of this betrayal. Perhaps it does not matter ("Es lo mismo"), for by purifying the emotion he abolishes all distinctions, converting the event into a polyvalent sign with both negative and positive meanings. The conclusion of the poem makes explicit the semiotic nature of the sound:

muy recogidamente, como a fronda

Dolor que oigo

mecida, sin buscar señas, palabras

o significación. Música sola,

sin enigmas, son solo que traspasa

mi corazon, dolor que es mi victoria.

At this point the purification of the poet's sorrow is complete. The sound, originally a sign for this emotion, has become an autonomous signifier, a purely musical sign that no longer calls for interpretation. The poet has triumphed over his emotion by transforming it into a sign, exploring this sign's ambiguity, and finally asserting its autonomy. The poem moves from "dolor" to "resignación," and, in the paradox of the last line, to "victoria."

"Como el son de las hojas del álamo," like "Brujas a mediodía" and "Gestos" exemplifies a basic paradigm at work in Alianza y Condena as a whole. In each of these poems the poet's starting point is a predominately negative view of both language and reality. Through a meditation on the arbitrariness of the sign he is able to rediscover a more hopeful vision. Perhaps the best way of understanding this pro- cess is through an examination of the title of the collection. The most obvious reading is a direct contrast between the two terms: "alianza vs. condena." As José Luis Cano has exclaimed: "alianza con ese sol que brilla puro, con esa patria desnuda y verdadera ... condena de todo lo que ensucia, con su falsedad, su impureza, la verdad de una tierra y de un pueblo" (158). Alianza however, can also be a negative concept. The word can refer to an alliance in the military sense, a social contract built on fear rather than love. In this second interpretation, "alianza como condena," a fearful defensiveness stands in contrast to true social communion: "¿cómo fortificar aqui la vida / si ella es sólo alianza?" (164). The reading suggested by the poems in the third section, finally, is "alianza en condena," or "condena como alianza" ("Dolor que es mi victoria"). The poet finds paradoxical comfort in his condemnation; he is able to perceive a saving grace in his seemingly miserable circumstances.

The alternate readings of the title phrase arise from an awareness of the reversibility of terms, the essential ambiguity of words. In the case of the last reading this ambiguity allows for a potential escape from the devastatingly critical vision of language and reality, In poems such as "Brujas a mediodía," "Ciudad de meseta," "Cáscaras," and "Nieve en la noche" the arbitrariness of the sign allows the poet to strip away the pleasant illusions of reality in order to face the negative truth. The same principle of arbitrariness, however, ultimately leads him to question this "truth" as yet another deceptive sign. His consciousness of the duplicity of language can be liberating as well as destructive.

The sign in Alianza y Condena is essentially ambiguous; it is potentially either true or deceitful, positive or negative. Thus the critical vision, suspicious of both language and reality, can be reversed: the poet's salvation appears to him disguised in a destructive form. The unmasking of a positive reality concealed by an apparently negative sign leads to a final possibility, a language that truly coincides with its positive referent. The two, somewhat longer than average poems that comprise the fourth and final section of the book, "Oda a la niñez" and "Oda a la hospitalidad," explore the possibility of a return to a more innocent vision of the sign. The desire for a simpler relation to the world expressed 
in these poems recalls the pastoral aspirations of Rodríguez's previous books, Don de la ebriedad and Conjuros. In these final poems of Rodriguez's third volume, however, the poet retains his awareness of the dangers of self-deception. Ever conscious of the duplicity of language, he searches for a paradoxical "wise innocence" that will overcome the powerful sense of desengaño that dominates the earlier poems in the book.

Like many other poems in Alianza, "Oda a la niñez" begins on a negative note. The return of innocence takes the ironical form of a cold March day:

¿Y esta es tu bienvenida, marzo, para salir de casa alegres: con viento humedo y frío de meseta? Siempre ahora, en la puerta, y aún a pesar nuestro, vuelve, vuelve este destino de niñez que estalla en todas partes: en la calle, en esta voraz respiración del día, en la sencillez del primer humo sabroso, en la mirada, en cada laboreo del hombre (187).

This "destino de niñez" is presented as an exception to the normal world of everyday life:

Siempre así, de vencida,

sólo por miedo a tal castigo, a tal

combate, ahora hacemos

confuso vocerío por ciudades,

por fábricas, por barrios

de vecindad. Mas tras la ropa un tiemblo

nos tañe, y al salir por tantas calles

sin piedad y sin bulla

rompen claras escenas

de amanecida, y tantos

sucios ladrillos sin salud se cuecen

de intimidad de lecho y guiso. Entonces,

nada hay que nos aleje

de nuestro hondo oficio de inocencia (187-88).

This last phrase, which echoes the earlier "destino de niñez," provides an essential key to the poet's attitude. Innocence here is not a natural state which can simply be taken for granted, but rather an "oficio," a craft or trade and a calling as well (the Spanish word has strong ecclesiastical connotations). Moreover, the return to innocence is frightening: it is presented as a "castigo" and a "combate."

The pattern of alternation between the negative circumstances of everyday life and the return of hope continues throughout "Oda a la ninez." The second of the four romannumeraled sections consists of a litany of denunciations, reminiscent of many earlier poems of Alianza. This section culminates in a rhetorical question - "¿Por qué todo es in- fancia?" (189) - that leads to the repeated refrain in the third section, "Ved que todo es infancia" (189-90). This phrase introduces a further list of the circumstances, mostly negative, of the poet's everyday life, including a condemnation of the backruptcy of language:

... nuestras

palabras que ahora,

al saludar, quisieran

ser panales y son

telas de araña, nuestra

violencia hereditaria,

la droga del recuerdo, la alta estafa del tiempo,

la dignidad del hombre

que hay que abrazar y hay

que ofrecer y hay

que salvar aquí mismo,

en medio de esta lluvia fría de marzo ...

Ved que todo es infancia (189-90).

The appearance of a more positive element such as "la dignidad del hombre" in this list is surprising. Even more strange is the grouping together of these diverse elements under the general heading of "infancia." (None of the conventional associations of childhood enters into the picture.) It is as if the poet were attempting to reduce his experience in all of its complexity into a single word, one that connotes innocence, purity, and happiness everything that this experience is not.

The fourth and final section of "Oda a la niñez" further defines the poet's paradoxical conception of childhood: "Lo de entonces fue sueño. Fue una edad. Lo de ahora / no es presente o pasado, / ni siquiera futuro: es el origen" (190). It is clear that the poet does not desire a nostalgic return to a happier time: as always, he rejects "la droga del recuerdo." Rather he wishes to regain a sense of the pristine innocence of the world, an almost mystical state that can occur even in the worst of circumstances:

Esta es la única hacienda

del hombre. Y cuando estamos llegando y ya la lluvia

zozobra en nubes rápidas y se hunde por estos arrabales

trémula de estertores luminosos, bajamos la cabeza

y damos gracia sin saber qué es ello, qué es lo que pasa, quién a sus maneras nos hace, qué herrería, qué inmortal fundición es ésta. Y nadie, nada hay que nos aleje de nuestro oficio de felicidad sin distancia ni tiempo.

Es el momento ahora

en el que, quièn lo diría, alto, ciego, renace el sol primaveral de la inocencia,

ya sin ocaso sobre nuestra tierra (190-91). 
Whereas "Oda a la niñez" is a metaphorical journey in time, the final poem of Alianza $y$ Condena, "Oda a la hospitalidad," is a poem of homecoming. It is significant that Rodríguez, who had been living and teaching in England since 1957, returned to live in Spain in 1965, the year of publication of Alianza. "Oda a la hospitalidad" begins with the image of a wanderer in search of comfort:

En cualquier tiempo en cualquier terreno siempre hay un hombre que anda tan vagabundo como el humo, bienhechor, malhechor,

bautizado con la agria

leche de nuestras leyes. Y él encuentra su salvación en la hospitalidad (192).

The pattern found in "Oda a la niñez" is repeating itself once again: the wanderer, clearly the poet's double, finds salvation in spite of his circumstances:

Forastero, ve cómo

una vieja mentira se hace una verdad nueva.

Ve el cuerpo del engaño

y lo usa: esa puerta

que, al abrirse, rechina

con cruel desconfianza, con amargo reproche.

Returning to his native land as a stranger, the protagonist must virtually reinvent his past:

hacer de su pasado

$¿$ Mas alguien puede

simple materia de revestimiento:

cera, laca, barniz, lo que muy pronto

se marchita, tan pronto,

como la flor del labio?

$¿ O$ bien ha de esperar a estar con esos

verdaderos amigos, los que darán sentido

a su vida, a su tierra y a su casa?

This re-vision of the past cannot be a superficial one: in light of his earlier critique of deceptive appearances the poet rejects the possibility of merely creating another illusory facade, painting over his life with "cera, laca, barniz."

The final section of the poem contains many echoes of its companion piece. Like "Infancia," the key concept of "Oda a la hospitalidad" is associated with a moment of origin:

Es la hospitalidad. Es el origen

de la fiesta y del canto.

Porque el canto es tan sólo

palabra hospitalaria: la que salva

aunque deje la herida (194).

Here the moment of innocence is directly tied to a vision of language in general and of poetry in particular:
A pesar de que hagamos

de convivencia técnicas

de opresión y medidas

de seguridad, $y$

de la hospitalidad hospicios, siempre

hay un hombre sencillo y una mañana clara,

con la alta transparencia de esta tierra,

y una casa, y una hora

próspera.

As elsewhere in Alianza y Condena, simplicity, clarity, and transparency (words associated with the motivation of the sign) stand in opposition to the deceitful language of a corrupt society. The link between an inauthentic social order and words that do not correspond to reality is evident in the play on words: "hospitalidad hospicios."

The concluding lines of "Oda a la hospitalidad" depict a moment of true communal solidarity, rare in Rodriguez's poetry after Conjuros. Through his act of naming, the poet/ wanderer regains his link to his native land:

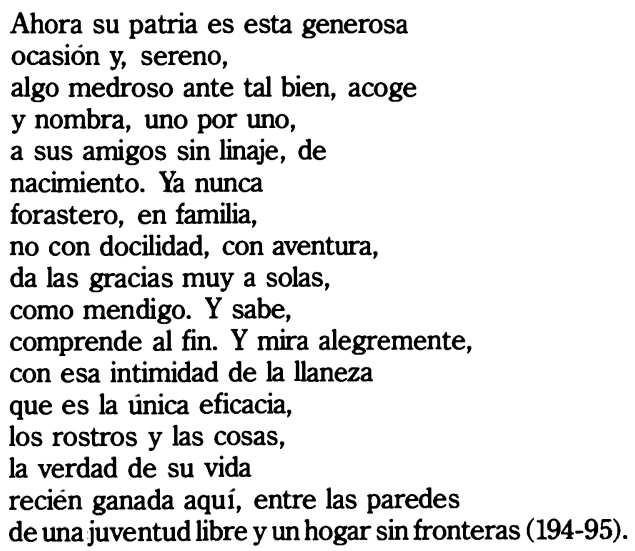

The similarities between these lines and the conclusion of "Oda a la niñez" are evident. In both cases the poet gives thanks for his rediscovery of a vision that dissolves both time and space. "Hospitalidad," like "niñez" represents an exceptional moment of vision when the poet is able to regain a more innocent relationship to the world. The two poems share a "happy ending": the poet concludes both with a sweeping affirmation of faith, one which collapses his complex vision of reality into a single dimension. Were it not for the larger context of Alianza y Condena, these statements would appear naive. Read within this context, the conclusions of the two poems represent the poet's affirmation of a possibility for a truthful language in spite of the essentially duplicitous nature of the sign.

From one point of view, then, the two odes 
that conclude Alianza y Condena represent a rediscovery of the innocence lost in the poet's debunking of illusions. Read in this way, the book as a whole would be the story of the transformation of a negative vision of the sign into a renewed faith in the powers of language to integrate the poet into the world. At the same time, the poet never loses his awareness of the arbitrariness of language in these final poems. In contrast to the "naive" viewpoint expressed in many of the poems in Conjuros, he continues to consider reality in all of its complexity. His language remains aware of itself: the achievement of the mystical moment of transcendence is the result of an "oficio," a self-conscious effort to transform a vision of reality through language. An alternate way of viewing the development of the book, then, is as a progression from a critical vision, a relatively simple view of deceptiveness of signs, toward a more complete view of language. The awareness of language revealed in these poems is no less complex than the critical vision in the beginning. If anything, the poet has transcended the simplistic view that equates the arbitrariness of the sign with the meaninglessness of the world.

$\mathbf{R}$ odríguez's poetry, from his earliest poems through his most recent works, is characterized by its use of paradoxical language. The standard account of the evolution of Rodríguez's poetry has it that the supposedly innocent, exalted, and unreflexive exclamations of Don de la ebriedad and Conjuros give way to the more meditative tone of his "mature" phase. The poet himself has summarized this development: "A lo mejor esta ebriedad un poco cósimica, sin ideas ni presupuestos morales, se vaya haciendo cada vez más moral, más meditativa" (Infame turba 231). Put in these terms, this comparison slights the complexity of the earlier work. Still, there is significant validity to the observation that Rodríguez's later poetry is much more cautious in its affirmation of hope. The powerfully critical vision that characterizes so many of the poems in Alianza y Condena can never be overcome entirely, even in the most exceptional moments of renewed innocence. Innocence is, precisely, an exception in a world of deceptive appearances: it does not come naturally, but must be achieved through a self-conscious manipulation of the dialectics of language. Alianza y Condena, then, ends on a paradoxical note. The trajectory of the volume moves from a distrust of all language toward an innocent view of the sign. Yet this new vision remains aware of its own status as language. It is the principle of the arbitrariness of the sign that ultimately allows the poet to regain his faith in the word.

\section{NOTES}

'I am employing the term "dialectic" in the sense given by Kenneth Burke: "the employment of the possibilities of linguistic transformation" (A Grammar of Motives 402). Other relevant definitions might include: "the discovery of truth by the give and take of converse and redefinition ... the processes of interaction between the verbal and the non-verbal ... the internal dialogue of thought ... the placement of one thought or thing in terms of its opposite ... the progressive or successive development and reconciliation of opposites" (403).

"José Olivio Jimenez also reads Alianza y Condena as a search for knowledge or truth, but without exploring Rodríguez's specifically linguistic consciousness.

${ }^{3}$ Persin studies the use of rhetorical questions, along with other forms of equivocating syntax such as negation, antithesis, and the subjunctive mood. See especially her analysis of "Brujas a mediodía" (83-91).

"Siebenmann points out that the notion of the gesture is a metaphor for all forms of human communication (46366). Nevertheless he stops short of considering the poem as metapoetry of a more explicit variety.

${ }^{5}$ The notion of the poem as a creative act of exploration underlies the poetics of Rodríguez's entire cohort. The title of Debicki's book, Poetry of Discovery, refers to this aspect of these poets' work. Discovery in this case translates conocimiento, a key word for Rodríguez, Valente and their group.

${ }^{6}$ Persin, for example, speaks of his "intuitive rather than logical approach toward language" (91). Such statements, although they can be supported by some of the poet's statements about his own work, do not take into account the depth and coherence of Rodríguez's meditation on the sign.

TThe idea of the transcendent transformation of reality is frequent in Rodríguez criticism. See Bousoño, Debicki, and Bradford. None of these critics, however, has seen this phenomenon in specifically semiotic terms, as an interpretation of the signs of the world.

${ }^{8}$ The poets of Rodríguez's generation were children during the Spanish civil war. Any nostalgia that they might feel for their childhood is tempered by the knowledge of the national tragedy that was occurring at the time. In Jaime Gil de Biedma's "Intento formular mi experiencia de la guerra" the child's naive happiness - "Fueron, posiblemente, / los años más felices de mi vida" (Las personas del verbo 122) - contrasts with the adult poet's subsequent awareness of the war: "Mis ideas de la guerra cambiaron / después, mucho despues / de que hubiera empezado la postguerra" (124).

\section{WORKS CITED}

Bousoño, Carlos. "La poesía de Claudio Rodríguez." Poesia 1953-1966. By Claudio Rodriguez. Barcelona: Plaza y Janés, 1971. 9-35.

Bradford, Carole A. "Transcendent Reality in the Poetry 
of Claudio Rodríguez." Journal of Spanish Studies: Twentieth Century 7 (1979): 133-46.

Burke, Kenneth. A Grammar of Motives. New York: Prentice Hall, 1945.

Cano, José Luis. "La poesía de Claudio Rodríguez de Conjuros a Alianza y Condena." Poesia española contemporánea: generaciones de posguerra. Madrid: Guadarrama, 1974. 153-64.

Debicki, Andrew P. "Claudio Rodríguez: Language Codes and Their Effects." Poetry of Discovery: The Spanish Generation of 1956-1971. Lexington, Kentucky: The University Press of Kentucky, 1982. 40-58.

Gil de Biedma, Jaime. Las personas del verbo. Barcelona: Seix Barral, 1982.

Jimenez, Jose Olivio. “Hacia la verdad en Alianza y Con- dena (1965) de Claudio Rodriguez." Diez años de poesia española, 1960-1970. Madrid: Insula, 1972. 145-74.

Mudrovic, William Michael. “Claudio Rodríguez's Alianza y Condena: Technique, Development and Unity." Symposium 33 (Fall 1979): 248-62.

Persin, Margaret. "The Syntax of Assertion in the Poetry of Claudio Rodriguez." Recent Spanish Poetry and the Role of the Reader. Lewisburg: Bucknell University Press, 1987. 68-97.

Rodríguez, Claudio. Alianza y Condena. Madrid: Revista de Occidente, 1965.

1983.
Desde mis poemas. Madrid: Catedra, 